\title{
Seasonal limnetic feeding regime of the "robalo" Eleginops maclovinus (Valenciennes 1830), in the Valdivia river, Chile
}

\section{Regimen estacional de alimentación limnética en el "robalo" Eleginops maclovinus (Valenciennes 1830), en el río Valdivia, Chile}

\author{
Germán Pequeño ${ }^{1 *}$, Héctor Pavés ${ }^{1}$, Carlos Bertrán ${ }^{1}$. \& Luis Vargas-Chacoff ${ }^{1}$. \\ 1Instituto de Zoología "Ernst F. Kilian”, Universidad Austral de Chile, Valdivia, Chile. \\ *E-mail: gpequeno@uach.cl
}

\begin{abstract}
The "robalo" Eleginops maclovinus (Valenciennes 1830) is a common fish in the littoral, estuaries and rivers (under tidal effects zone) of southern South America, including the Falkland islands. The feeding habits of this species is known mainly in the two first mentioned habitats, where it consumes mostly animals from marine and estuarine origin. However, little is known about its seasonal feeding habits in limnetic environments. It is only assumed that it has to eat preys from freshwater origin. In the present study, 127 specimens of E. maclovinus were analysed, 119 of which had stomach contents. The zoophagic tendency of the species is corroborated, but also animals from low salinities and limnetic salinities were found to be consumed in the freshwater environment. Consequently, E. maclovinus appears as an extraordinarily versatile species, in relation to its feeding capacities, with physiologic characteristics allowing a wide osmoregulatory spectrum at the digestive level, probably one of the most variable within the suborder Notothenioidei, which has strong Antarctic links.
\end{abstract}

KEYwORDs: Feeding, seasonality, Eleginopsidae, physiological versatility, Chile.

\section{RESUMEN}

El "robalo" Eleginops maclovinus (Valenciennes 1830) es una especie de pez común en el litoral, estuarios y ríos (bajo efectos de mareas) en el sur de Sudamérica, incluyendo las Islas Malvinas. Sus hábitos alimentarios son conocidos en los dos primeros ambientes mencionados, donde consume principalmente animales de origen marino y estuarial. Sin embargo, poco o nada se sabe sobre su alimentación estacional en aguas dulces, salvo la suposición que allí debe comer presas de origen dulceacuícola. En el presente estudio se analizaron 127 ejemplares de E. maclovinus, de los cuales 119 tuvieron contenido estomacal. Se ha corroborado su tendencia zoofágica, pues en el contenido estomacal se encontraron animales de salinidades bajas y limnéticas, que fueron consumidos en aguas dulces. Así, E. maclovinus aparece como una especie extraordinariamente versátil en cuanto a sus capacidades alimentarias, con una fisiología que le permite aceptar un amplio espectro osmorregulatorio a nivel digestivo, probablemente uno de los más variables dentro del suborden Notothenioidei, de supuesto origen antártico.

Palabras Clave: Alimentación, estacionalidad, Eleginopsidae, versatilidad fisiológica, Chile. 


\section{INTRODUCTION}

The "robalo" Eleginops maclovinus (Valenciennes 1830) is a monotypic species from the family Eleginopsidae (Nototheniodei), which is distributed in southern South America, mainly in marine and estuarine environments (although the authors have also collected specimens in limnetic environments).

A series of studies have been carried out in South America in an attempt to characterize the trophic relations of this species on individuals from marine, estuarine, and limnetic habitats, and have shown an ontogenetic change in the robalo prey items. Two consistent hypothesis came out from these studies: 1) juvenile robalo vary their normally carnivorous diet to include herbivorous behavior in the adult stage (Guzmán \& Campodónico 1973, Gosztonyi 1979); 2) the robalo is an omnivorous predator with carnivorous habits throughout most of its' life (Pequeño 1979, Turner 1988, Paves et al. 2005). Studies have not been made on the larval or early juvenile stages of E. maclovinus.

It should be noted that the ontogenetic variation in the diet from carnivorous to herbivorous could be related to the availability of food within the environment more than to selectivity excercised by the robalo as a predator (Acevedo 1994 , Licandeo et al. 2006). This situation would imply that the robalo would consume either plant or animal material according to the type of food present in the environment at any given time. Clarification on this point would allow a conclusion on whether E. maclovinus was an opportunistic or selective predator (Jaksic 2000). During winter conditions when quantities of prey items decline considerably, the diet should become oriented towards the most prevalent resources, or those more easily obtained (e.g., plants).

Within this context, the present study attempts to determine the trophic relationships of juveniles of E. maclovinus in a limnetic habitat during different seasons. Attempts are made to determine the existence of seasonality in the diet of these fishes as a function of food availability in the environment. In order to fulfill this objective, data generated here are compared with data obtained by Pavés et al. (2005) in the same study area.

\section{MATERIALS AND METHODS}

\section{SAMPLES}

A total of 127 individuals of E. maclovinus were caught between 17 and 20 March 2002 (summer) and on 4 August 2003 (winter). Catches were obtained in the region of Las Mulatas $\left(39^{\circ} 50^{\prime} \mathrm{S} ; 73^{\circ} 15^{\prime} \mathrm{W}\right)$ using a gillnet with a mesh opening of $32 \mathrm{~mm}$, with an overall length of $30 \mathrm{~m}$ and height of $1.75 \mathrm{~m}$. Las Mulatas is located at about $16 \mathrm{~km}$ from the Pacific Ocean on the Valdivia River estuary (Fig.1), and represents the upper limit of brackish water incursion (Pavés et al. 2005). Methods for sample preparation and analysis were similar to those used by Pavés et al. (2005), weighing and measuring all the specimens obtained.

ANALYSIS OF STOMACH CONTENTS

The stomach was removed from each specimen, and the stomach contents were analyzed.

Prey items recovered from the stomachs contents were separated by taxonomic group. Taxonomic identifications were made to the lowest possible taxonomic level. Preys were counted, and their frequency $(\% \mathrm{~F})$ and abundance of occurrence in the stomachs $(\% \mathrm{~N})$ were recorded. An index of relative prey importance (IIR, Pinkas et al. 1971) was then calculated, expressing a value for relative importance of items in stomach contents of the predator, as follows:

$$
\operatorname{IIR}=(\% \mathrm{~F} \times \% \mathrm{~N}) / 100
$$

Comparisons were carried out among seasons for each $\% \mathrm{~F}$ and $\% \mathrm{~N}$ using a $\chi_{\mathrm{c}}^{2}$ (Chi- ${ }^{2}$ with Yates correction) for $2 \times 2$ contingency table) in order to compare densities value between sectors sampled and seasons (Zar 1999). A plot was also made of $\% \mathrm{~F} v s \mathrm{~A}$ (abundance of preys), in order to quantify the food offering in the environment in relation to items taken by the robalo.

CHARACTERIZATION OF THE FOOD OFFERING IN THE ENVIRONMENT Fishes and other benthic fauna were sampled from the Valdivia River at Las Mulatas and Los Pelúes (18 km to the north of Las Mulatas) on the same dates as for the robalo sampling described above. This sampling included recovery of bottom sediments to obtain the macrofauna, and electric fishing for the fish fauna.

Methodology for collecting, sorting, and analysis of the macrofauna was similar to that described by Pavés et al. (2005). Electric fishing for small fishes was carried out using electric fishing equipment (EFKO, model FEG 1000, $1 \mathrm{KW}, 150-600 \mathrm{~V})$. This activity was carried out from the shore at both sampling sites, especially among reeds and nearshore vegetation. In the text, a specific part of a sample will be named " $n$ ", the size of the whole sample will be "N" and the average value for different data will be " $x$ ".

\section{RESULTS}

The average size of the $127 \mathrm{E}$. maclovinus obtained at Las Mulatas was $27 \mathrm{~cm}$ TL $(\mathrm{SD}=4.5 \mathrm{~cm}$, range 18.0 to $42 \mathrm{~cm}$, live) and the average weight was $226.6 \mathrm{~g}$ (SD = $141.3 \mathrm{~g}$ fresh, range 75 to $472 \mathrm{~g}$ live weight, Fig $2 \mathrm{a}, \mathrm{b}$ ). 


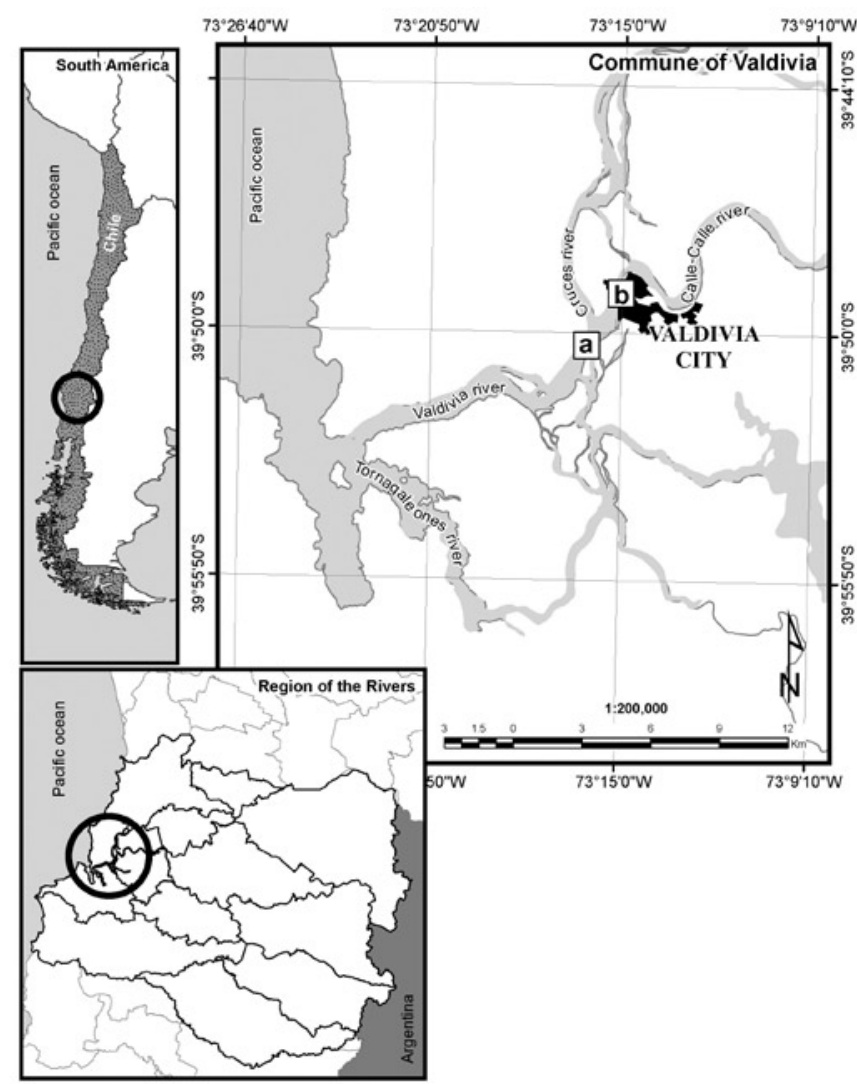

FIGURE 1. Geographical location of the field sampling stations: a) Las Mulatas, b) Los Pelúes.

FIGURA 1. Ubicación geográfica de las estaciones de muestreo: a) Las Mulatas, b) Los Pelúes.

No statistically significant differences in lengths (KruskalWallis test; $\mathrm{H}_{(1, \mathrm{~N}=126)}=2.57, \mathrm{p}=0.10$ ) or weights (Kruskal Wallis test $\left.\mathrm{H}_{(1, \mathrm{~N}=126)}^{(1, \mathrm{~N}=126)}=0.91, \mathrm{p}=0.33\right)$ of the robalos were observed between the different seasons sampled (Pavés et al. 2005). Based on the the lengths of the fishes obtained, the males were probably between two and four years of age, and thus immature (Gozstonyi 1974, Calvo et al.1992, Licandeo et al. 2006).

The fish fauna accompanying the robalo catches included both limnetic and estuarine species such as Oncorhynchus mykiss Walbaum, 1792, Galaxias maculatus Jenyns,1842, Galaxias platei (Steindachner 1898), Odontesthes regia (Humboldt, 1821), Basilichthys australis Eigenmann, 1927, Cauque mauleanum Steindachner, 1896, Cheirodon sp., Percichthys trucha (Valenciennes 1833) and Mugil cephalus Linneaus, 1758.
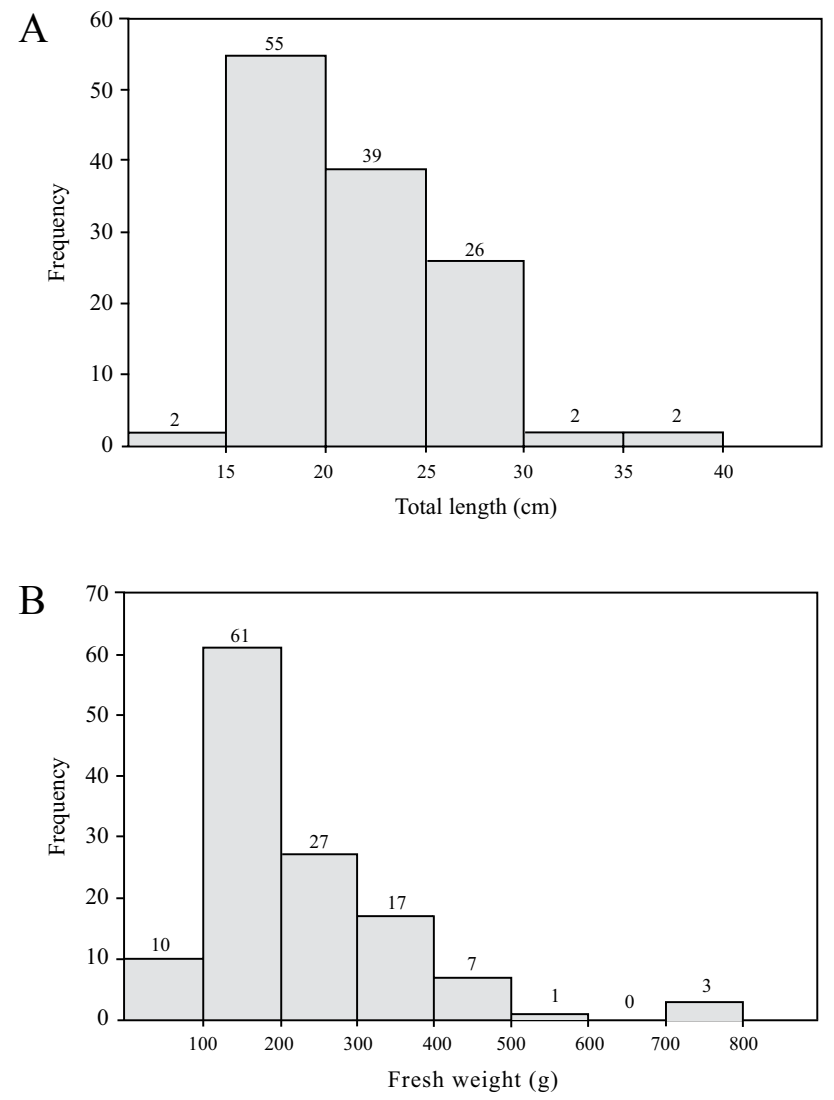

FIGURE 2. Characteristics of Eleginops maclovinus specimens captured in Las Mulatas: (a) Frequency of total length (TL) and (b) Frequency of fresh weight.

Figura 2. Características de los ejemplares de Eleginops maclovinus capturados en Las Mulatas: (a) Frecuencia del largo total (TL) y (b) Frecuencia de peso fresco.

OvERALl STOMACH CONTENTS ANALYSIS

Almost all the stomachs analyzed $(92.1 \%, \mathrm{n}=117)$ had contents. Within these, identification was possible to the species or higher taxonomic level both in plant and animal preys. Only $7.9 \%(n=10)$ of the stomachs were empty.

The analysis of stomach contents showed a broad group of food items being consumed by the robalo, accompanied by a large amount of ingested material including sand and gravel (e.g. schists, mica). Among the food items observed were algae and plant material, gastropods, crustaceans, insects, and fishes. A total of $92.1 \%(\mathrm{n}=117, \mathrm{~N}=127)$ of the stomachs contained animal remains, and $80.3 \%(\mathrm{n}=102$, $\mathrm{N}=127$ ) contained plant remains. Overall, $98.7 \%$ of items identified from the stomachs in March, and $99.53 \%$ of those from August were of animal origin, while corresponding figures for plant matter were 1.1 and $0.47 \%$ (Table 1). 
Gayana 74(1), 2010

TABLE 1. Comparison between Percentage in Numbers (Abundance), Frequency of Occurrence and Index or Relative Importance (IIR) of items identified within the stomach contents of Eleginops maclovinus captured in March (summer) and August (winter), in the Valdivia river. $\chi^{2} \mathrm{c}$ values are given.

TABla 1. Comparación entre Porcentajes en Números (Abundancia), Frecuencia de Ocurrencia e Indice de Importancia Relativa (IIR) de ítemes identificados en el contenido estomacal de Eleginops maclovinus capturados en marzo (verano) y agosto (invierno), en el río Valdivia. Se entregan valores $\chi^{2} c$.

\begin{tabular}{|c|c|c|c|c|c|c|c|c|}
\hline & \multicolumn{3}{|c|}{ Frequency Number $(\% \mathrm{~N})$} & \multicolumn{3}{|c|}{ Frequency of Occurrence $(\% \mathrm{~F})$} & \multirow[b]{2}{*}{$\begin{array}{c}\text { IRI } \\
\text { March }\end{array}$} & \multirow[b]{2}{*}{$\begin{array}{c}\text { IRI } \\
\text { August }\end{array}$} \\
\hline & March & August & $\chi^{2}$ & March & August & $\chi^{2}$ & & \\
\hline Crustacea & 97.367 & 73.399 & $7885.580^{*}$ & 93.200 & 90.910 & 0.006 & 90.75 & 66.73 \\
\hline Corophiidae & 97.148 & 72.032 & $8161.460 *$ & 93.200 & 90.909 & 0.006 & 90.54 & 65.48 \\
\hline Tanaidacea & 0.171 & 0.000 & $12.388^{*}$ & 13.590 & 0.000 & 2.139 & 0.02 & 0.00 \\
\hline Ciprinidae & 0.033 & 0.063 & 1.050 & 9.710 & 4.545 & 0.131 & 0.00 & 0.00 \\
\hline H. crenulatum & 0.008 & 0.038 & 3.082 & 4.850 & 9.091 & 0.075 & 0.00 & 0.00 \\
\hline Idotheinae & 0.005 & 1.266 & $736.168^{*}$ & 2.910 & 13.636 & 2.517 & 0.00 & 0.17 \\
\hline Zoea larvae & 0.002 & 0.000 & 1.462 & 0.970 & 0.000 & 0.730 & 0.00 & 0.00 \\
\hline Gastropoda & 0.035 & 0.025 & 0.008 & 19.420 & 4.550 & 1.903 & 0.01 & 0.00 \\
\hline L. cumingii & 0.033 & 0.025 & 0.000 & 18.450 & 4.545 & 1.675 & 0.01 & 0.00 \\
\hline Bivalvia larvae & 0.002 & 0.000 & 1.462 & 0.970 & 0.000 & 0.730 & 0.00 & 0.00 \\
\hline Annelida & 0.000 & 0.747 & $447.049 *$ & 0.000 & 36.360 & $34.175^{*}$ & 0.00 & 0.27 \\
\hline Polychaeta & 0.000 & 0.747 & $447.049^{*}$ & 0.000 & 36.364 & $34.175^{*}$ & 0.00 & 0.27 \\
\hline Insecta & 1.518 & 25.247 & $9694.371^{*}$ & 69.900 & 86.360 & 0.797 & 1.06 & 21.80 \\
\hline Chironomidae & 1.505 & 25.247 & $9730.569^{*}$ & 67.960 & 86.364 & 2.164 & 1.02 & 21.80 \\
\hline Hygrobatidae & 0.003 & 0.000 & 0.360 & 1.940 & 0.000 & 0.077 & 0.00 & 0.00 \\
\hline Trichoptera & 0.003 & 0.000 & 0.360 & 1.940 & 0.000 & 0.077 & 0.00 & 0.00 \\
\hline Inderminatae & 0.007 & 0.000 & 0.004 & 2.910 & 0.000 & 0.002 & 0.00 & 0.00 \\
\hline Teleostei & 0.002 & 0.110 & $53.247^{*}$ & 0.970 & 18.180 & $9.861^{*}$ & 0.00 & 0.02 \\
\hline Teleostei & 0.002 & 0.110 & $53.247 *$ & 0.970 & 18.180 & $9.861^{*}$ & 0.00 & 0.02 \\
\hline Plantae & 1.078 & 0.468 & $25.415 *$ & 46.600 & 59.090 & 1.512 & 0.50 & 0.28 \\
\hline S.californicus & 0.228 & 0.468 & $14.924 *$ & 28.160 & 40.909 & 0.856 & 0.06 & 0.19 \\
\hline Filaments & 0.850 & 0.000 & $66.494 *$ & 42.720 & 45.455 & 0.000 & 0.36 & 0.00 \\
\hline TOTAL & 60985 & 7902 & & 103 & 22 & & & \\
\hline
\end{tabular}

$*=$ Statistically significant difference according to $\chi^{2} \mathrm{c}$ test.

The taxon with the highest frequency (FO\%) of occurrence in the stomachs was Crustacea during both sampling seasons $(x=92 \%)$, followed by Insecta $(x=$ $78 \%)$, Plantae $(\mathrm{x}=52 \%)$, Annelida $(\mathrm{x}=18 \%)$, Gastropoda $(\mathrm{x}=11 \%)$ and lastly Teleostei $(\mathrm{x}=<1 \%)$. In relation to the number of specimens by taxon $(\mathrm{N} \%)$, the class Crustacea represented, in average, $85 \%$ between both seasons, followed by insects $(x=13 \%)$, and then Plantae, Gastropoda, Annelida and Teleostomi with a proportion lower than $1 \%$ (Table 1 ).
ANALYSIS BY SYSTEMATIC GROUP

Statistically significant differences were observed in N\% values for Crustacea preys between the two evaluated seasons, with a greater numerical percentage during summer, compared with winter $\left(\chi_{\mathrm{c}}^{2}=7885.580\right.$, d.f. $=1$, $\mathrm{p}<0.05$; Table 1). On the other hand, the $\mathrm{N} \%$ values for the Insecta were greater in winter compared to summer $\left(\chi_{\mathrm{c}}^{2}=9694.371\right.$, d.f. $=1, \mathrm{p}<0.05$; Table 1$)$. No statistic difference was found in $\mathrm{FO} \%$ between Crustacea and Insecta. The other items showed broad variations in $\% \mathrm{~N}$, 
but only two items showed difference in \%FO between seasons (Table 1) Annelida, and Teleostei. The Annelida showed a significant increase $\left(\chi_{\mathrm{c}}^{2}=34.175\right.$, d.f. $\left.=1, \mathrm{p}<0.05\right)$ together with the Teleostei $\left(\chi_{c}^{2}=9.861\right.$, d.f. $\left.=1, p<0.05\right)$. The other items showed similar frequencies of occurrence between seasons (Table 1).

Class Crustacea: In this group the main taxon, both in numerical abundance and in frequency of occurrence in the stomachs for both seasons was the lacustrine amphipod Paracorophium hartmannorum Andres, 1979 (Corophiidae). This species represented over 90\% of the prey individuals in 70 to $90 \%$ of the stomachs analyzed (Table 1). Other crustaceans identified included the Tanaidacea (Malacostraca), Ciprinidae (Ostracoda), Hemigrapsus crenulatus (Milne Edwards 1837) (Decapoda), and Idotheinae (Valvifera-Isopoda), representing each one less than $1 \%$ of all individuals.

Class Gastropoda: Only one species of gastropod, Littoridina cumingi (d'Orbigny 1835), was present although its' frequency of occurrence was less than $20 \%$, an its abundance was below $1 \%$. No difference in $\% \mathrm{~N}$ and $\% \mathrm{~F}$ was found between seasons. Additionally, a "D" stage bivalve larva was identified, but only during summer (Table 1).

Phylum AnNelida: The only class identified within this group was Polychaeta, with a $\% \mathrm{~N}$ of less than $1 \%$, and an $\% \mathrm{~F}$ of $36 \%$ only in the August (winter) sampling (do not founded in March), and showing statistically significant differences in $\% \mathrm{~N}$ and $\% \mathrm{~F}$ between the seasons (Table 1).

Class InseCta: The most important taxon identified within this group was Diptera (fam. Chironomidae), with an abundance of 1 to $25 \%$, and a frequency of occurrence between 68 and $86 \%$. It was the second most important item consumed by the robalo. The remaining insects belonged to the Trichoptera family (tubes only), and an hygrobatid acarid, representing less than $1 \%$ in abundance and 3\% in frequency of occurrence (Table 1). The chironomids were the only insect group showing statistically significant differences in presence between seasons $\left(\chi_{c}^{2}=9730.569\right.$, d.f. $=1, p<0.05)$, although their frequency of occurrence did not vary (Table 1$)$.

Class Teleostei: This taxon was represented during the first season (summer) by an individual in an advanced stage of decomposition, which could not be identified to species. This item represented less than $1 \%$ in both frequency and abundance. In winter, seven specimens of Galaxias maculatus, one of Galaxias platei, and one indeterminate salmoniform (assumed to be Osmeriformes) were observed. There were statistically significant differences in number and frequency of occurrence between seasons (Table 1).

LACUSTRINE PLANTS: A total of 46.6 of the stomachs contained remains of lacustrine plants, either as vegetative structures or seeds. The only species identified, based on the seeds, was Scirpus californicus (C.A.Mey.) Steud. 1841 (Ord. Cyperaceae). Its' frequency of occurrence ranged between 28 and $41 \%$, with abundance of less than $1 \%$ (Table 1 ). Additionally, an indeterminate and filamentous estuarine organism (no identified) occurred in 42.42 and $45.45 \%$ of the stomachs with abundance near $1 \%$. These algae formed filamentous clumps which impaired quantification although they were one of the most frequent items recorded from stomachs of E. maclovinus (Table 1).

Nematode PARASITES: These occurred in 53.4\% in summer and $68.2 \%$ in winter of the stomachs analyzed, not showing significant statistical differences between seasons $\left(\chi_{c}^{2}=\right.$ 1.064, d.f. $=1, \mathrm{p}>0.05)$. During summer 115 nematodes were counted (mean $=1.1$ per stomach), and in winter, 37 (1.6 per stomach). Ascarophis sp. (fam.Cystidicolidae) was identified, with both mature males and females. Another group of helminth parasites included mature anisakids in $20.3 \%$ (March) and 31.4\% (August) of the stomachs. There were 19 larvae and 16 adults counted in this taxon.

\section{ANALYSIS BY FISH SIZE}

The robalo obtained were separated by size, into onecentimeter ranges, to give 14 ranges between 15 and $32 \mathrm{~cm}$. The only significant difference in stomach content by size of the fishes was for the Ciprinidae (Ostracoda) (KruskalWallis test $\left.\mathrm{H}_{(9, \mathrm{~N}=108)}=18.17, \mathrm{p}=0.033\right)$. For the other items there were no statistically significant differences between the different size ranges (e.g., Corophiidae, Kruskal-Wallis test; $\mathrm{H}_{(9, \mathrm{~N}=108)}=9.73, \mathrm{p}>0.05$; Teleostei, Kruskal-Wallis test; $\mathrm{H}_{(9,}$ $\mathrm{N}=108)=14.24, \mathrm{p}>0.05)$.

It was, however, possible to determine a positive correlation between the size and quantity of Teleostei (Spearman Rank test, $\mathrm{N}=108, \mathrm{R}=0.248, \mathrm{t}_{(\mathrm{n}-2)}=2.768, \mathrm{p}=0.006$ ), also determining a negative relation between size and quantity for the Corophiidae (Spearman Rank test, $\mathrm{N}=108, \mathrm{R}=$ $\left.-0.319, \mathrm{t}_{(\mathrm{n}-2)}=-3.631, \mathrm{p}=0.0004\right)$ and filamentous plants (Spearman Rank test, $\mathrm{N}=108, \mathrm{R}=-0.197, \mathrm{t}_{(\mathrm{n}-2)}=-2.165$, $\mathrm{p}$ $=0.032$ ). Idotheinae and Teleostei were observed in fishes beginning at $23 \mathrm{~cm} \mathrm{SL}$, increasing in numbers in larger sized robalo.

During the winter sampling the nematode parasites occurred at an $\mathrm{FO} \%$ of $45 \%$, with the askarophids most common at $36 \%$ occurrence $(\mathrm{n}=8 ; \mathrm{N}=22)$ and forming $38 \%$ of the parasites in the robalo $(\mathrm{n}=14, \mathrm{~N}=37)$; the highest frequency of parasites occurred in fishes of the 24$29 \mathrm{~cm}$ size class. 
Gayana 74(1), 2010

COMParisons BETWEen STOMACH CONTENTS AND THE MACROFAUNA OF THE VALDIVIA River

The species of macrofauna identified between the two seasons were similar, but its abundance between seasons was different. The most abundant groups in the environment were Annelida, Crustacea, and Insecta. In the first taxon, Prionospio sp. and Perinereis gualpensis Jeldes 1963 were the most important. Paracorophium hartmannorum (Corophiidae) was the only representative of the Crustacea present. Of Insecta, the most important groups were Chironomidae and Trichoptera (Table 2). There were differences in the presence of most organisms between areas and sampling stations, with P. hartmannorum remaining the only species not showing differences during summer between areas (Table 2). It was also noted that the average abundance of most of the organisms increased in winter, except for $P$. hartmannorum which reached its' highest levels in the summer (Table 2) and fishes that showed a decrease during winter (Table 2).
Most of the fishes obtained from the Valdivia River were Osmeriformes (Galaxias maculatus, Galaxias platei, and Oncorhynchus mikyss), Atherinopsidae (Odontesthes regia, and Cauque mauleanum) and Mugilidae (Mugil cephalus). The most abundant individuals included G. maculatus and O. regia (Table 2). Most of the fish fauna measuring less than $7 \mathrm{~cm}$ TL (probably due to capture methods mentioned in Pavés et al. 2005), showed statistically significant differences in numbers between sampling sites, as well as between the seasons sampled (Table 2). Most of the fish fauna sampled decreased in number during the winter, except for Cheirodon sp. and C. mauleanum. Figure 3 shows that $P$. hartmannorum, $P$. gualpensis, Chironomidae, Tricoptera, $G$. maculatus, G. platei, and Oncorhynchus sp. were common both in the robalo stomachs and environmental samples from Las Mulatas and Los Pelues. Although the sediments of the Valdivia River contained large numbers of polychaetes (e.g., Prionospio) and other annelids (e.g., Tubifex sp.) inhabiting habitats rich in organic material and low in oxygen, these organisms were not found in the robalo stomachs (Table 2, Fig. 3).

TABLE 2. Seasonal abundance of macrobenthos (individuals $/ \mathrm{m}^{2}$ ) and ichthyofauna (total of individuals) in the Valdivia river: Pelúes (1) and Las Mulatas (2). The average abundance for each sector (shore and talveg) and the percentages of variation (negative percentage $=$ decrease, positive percentage $=$ increase) are detailed.

TABla 2. Abundancia estacional del macrobentos (individuos $/ \mathrm{m}^{2}$ ) e ictiofauna (total de individuos) en el río Valdivia: (1) Pelúes y (2) Las Mulatas. Se detallan la abundancia promedio para cada sector (playa y talveg) y los porcentajes de variación (porcentaje negativo = disminuye, porcentaje positivo $=$ aumenta).

\begin{tabular}{|c|c|c|c|c|c|c|c|c|c|}
\hline \multirow[b]{2}{*}{ Species / Sector } & \multicolumn{3}{|c|}{ Summer } & \multicolumn{3}{|c|}{ Winter } & \multicolumn{3}{|c|}{ Average } \\
\hline & 1 & 2 & $\%$ Var & 1 & 2 & $\% \operatorname{Var}$ & Summer & Winter & $\%$ Var \\
\hline \multicolumn{10}{|l|}{ Macrobenthos } \\
\hline \multicolumn{10}{|l|}{ Annelida } \\
\hline Prionospio sp. & 210.5 & 1830.9 & 769.8 & 9207.5 & 20876.5 & 126.7 & 1020.7 & 15042 & 1373.7 \\
\hline Tubifex sp. & 94.7 & 0 & -100 & 4714 & 5629.5 & 19.4 & 47.4 & 5171.8 & 10811 \\
\hline P. gualpensis & 399.9 & 989.1 & 147.3 & 1115.5 & 2378 & 113.2 & 694.5 & 1746.8 & 151.5 \\
\hline \multicolumn{10}{|l|}{ Insecta } \\
\hline Chironomidae & 0 & 10.5 & 100 & 1999.5 & 1420.5 & 100 & 5.3 & 1710.0 & 32164.2 \\
\hline Trichoptera & 0 & 10.5 & 100 & 0 & 0 & 100 & 5.3 & 0 & -100 \\
\hline \multicolumn{10}{|l|}{ Crustacea } \\
\hline P. hartmannorum & 1525.8 & 1462.6 & -4.1 & 926 & 263 & -71.6 & 1494.2 & 594.5 & -60.2 \\
\hline \multicolumn{10}{|l|}{ Gastropoda } \\
\hline Eatoniella sp. & 0 & 0 & 0 & 63 & 0 & 0 & 0 & 31.5 & 100 \\
\hline \multicolumn{10}{|l|}{ Ichthyofauna } \\
\hline \multicolumn{10}{|l|}{ Teleostei } \\
\hline G. maculatus & 1535 & 18 & -98.8 & 114 & 46 & -59.6 & 776.5 & 80 & -89.7 \\
\hline G. platei & 11 & 0 & -100 & 2 & 4 & 100 & 5.5 & 3 & -45.5 \\
\hline O. mikyss & 1. & 0 & -100 & 0 & 0 & 0 & 0.5 & 0 & -100 \\
\hline Cheirodon sp. & 0 & 2 & 100 & 0 & 14 & 100 & 1 & 7 & 600 \\
\hline O. regia & 697 & 374 & -46.3 & 149 & 513 & 244.3 & 535.5 & 331 & -38.2 \\
\hline C. mauleanum & 9 & 0 & -100 & 32 & 0 & -100 & 4.5 & 16 & 255.6 \\
\hline M. cephalus & 13 & 6 & -58.3 & 0 & 0 & 0 & 9.5 & 0 & -100 \\
\hline
\end{tabular}




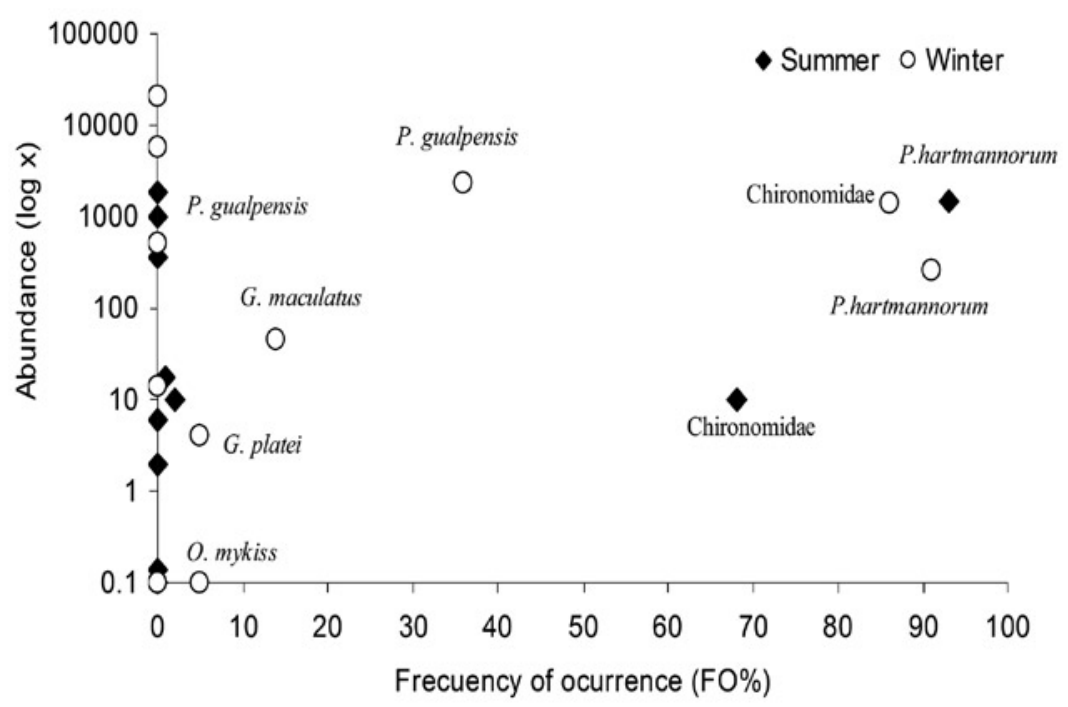

FIGURE 3. Comparison among frequency of occurrence (FO\%) of the main stomach items identified from Eleginops maclovinus, with the abundance of the macrofauna (specimens $/ \mathrm{m}^{2}$ ) and the ichthyofauna (specimens), captured at Los Pelúes and Las Mulatas sampling stations, in the Valdivia river estuary in summer and winter of the year 2003.

FIgURA 3. Comparación entre Frecuencia de Ocurrencia (FO\%) de los principales ítemes del contenido estomacal de Eleginops maclovinus y la abundancia de la macrofauna (especímenes $/ \mathrm{m}^{2}$ ) y la ictiofauna (especímenes), capturados en las estaciones de muestreo de Los Pelúes y Las Mulatas, en el estuario del río Valdivia en verano e invierno.

During summer, a high degree of predation pressure was exerted by E. maclovinus on $P$. hartmannorum and the Chironomidae; these prey items were not among the most abundant species between the sampling sites, nor between seasons (IIR, Table 1, Fig.3). Although it is assumed that $G$. maculatus was preyed upon by the robalo during summer, consumption of this species was low in spite of it's relative abundance in the environment (Tables 1,2).

Finally, it should be noted that E. maclovinus preyed upon the corophiid amphipod whether or not these were present in high or low abundance in the environment, which was also true for the Chironomidae. Conversely, although $G$. maculatus was present in greater numbers in the summer, it was preyed upon more in winter when its' numbers were lower (Fig. 3).

\section{DISCUSION}

In agreement with Pavés et al. (2005), the large percentage of E. maclovinus having stomach contents (92.1\%), the low degree of digestion of the prey, and the similarity of the prey ingested to species found in the environment, suggested that Las Mulatas was probably a feeding ground for the robalo.
The large variety of estuarine and limnetic food items recovered from E. maclovinus stomachs suggested that this species is a generalized feeder (Stuardo 1961, Ramírez et al. 1976, Pequeño 1979, Artigas et al. 1985, Jaramillo et al. 1985, Bertrán 1989, Ruiz 1993, Licandeo et al. 2006). The finding that the most important food items were $P$. hartmannorum and the chironomids was similar to previous findings (Pequeño 1979, Pavés et al. 2005). But different to the findings of Licandeo et al. (2006), who reported that the most important preys were $H$. crenulatus, E. analoga and Corophidae, all species from marine and estuarine system, where the robalo in the Licandeo et al. study were capture.

The diet of the robalo in the Valdivia River estuary was similar to that of other freshwater fish species such as O. mikyss and C. mauleanum (Artigas et al.1985, Klink \& Eckmann 1985). The prey, however, varied with the size of the fishes. Thus in robalo specimens of over $195 \mathrm{~mm}$ SL (225 mm TL) larger sized prey were taken, including $H$. crenulatus, Idotheinae, Littoridina cumingi, Teleostei, and Polychaeta. Some authors like Pequeño (1979) and Licandeo et al. (2006) founded H. crenulatus in specimen of robalo, this crusteacea also were founded in first specimen of robalo (measurement $225 \mathrm{~mm}$ TL) coinciding with these previous reports. The Idotheinae and 
Littoridina cumingi were found in robalo greater than 225 $\mathrm{mm}$ TL, and the Polychaeta and Teleostei in robalo greater than $275 \mathrm{~mm}$, respectively. The positive relation between the size and quantity of the Teleostei, compared with the negative relation between size and quantity of Corophiidae confirmed an ontogenetic change in prey in the robalo diet similar to the one presented by Licandeo et al. (2006).

In spite of this ontogenetic variation in prey species, the stomach contents of robalo of the Valdivia River both in summer (Pavés et al. 2005), and winter (present study), continue to suggest that this fish is a carnivore in marine, estuarine, and limnetic environments as described by Pequeño (1979), Turner (1988), Acevedo (1994), Isla \& San Román (1995), and Licandeo et al. (2006) in contrast to the hypothesis of Guzmán \& Campodónico (1973) cited in the Introduction section. The present research, although showing a high degree of frequency of occurrence of plant matter $(80.3 \%)$ in the robalo diet, showed its abundance to be significantly lower than $1 \%$ as stated by Pavés et al. (2005) for the summer season. Acevedo (1994) assumed that the carnivorous behavior of the robalo would be maintained over time based on the stability of the food offer in the environment.

Various species of polychaetes including Perinereis gualpensis, Prionospio sp., and the oligochaete Tubifex sp. that were found in sediment samples in the summer were not recovered from stomachs of $E$. maclovinus during this period (Pavés et al. 2005). In winter samples, only $P$. gualpensis occurred in the robalo stomachs, and then only in fishes of greater than $230 \mathrm{~mm}$ TL as noted in other study (Ruiz, 1993).

This seasonal change in diet may be related to the variation in abundance of prey items in the environment, since the polychaetes increased in numbers in the Valdivia River during the winter (Fig. 3). Another group showing variation in the robalo diet was $G$. maculatus, which increased in the diet in winter although this prey species occurred in the environment in lower numbers during that season. The chironomids and P. hartmannorum had similar frequencies of occurrence in robalo stomachs during both seasons sampled (Table 1), although populations of the prey species fluctuated between seasons with the chironomids showing a peak in winter and the corophiids in summer. From these data it was concluded that the robalo seems to be a selective predator within the Valdivia River habitat, a characteristic that requires more studies to be confirmed.

If there is selectivity for an amphipod and the Diptera, why does the $\% \mathrm{~F}$ of other groups such as Galaxias spp. and P. gualpensis increase from summer to winter? A possible explanation for this observation is related to the lower abundance of the corophiid during the winter, which may fail to provide all the energetic needs of the robalo, leading to increased predation on other species such as polychaetes, or species that are easily caught due to their small size (e.g. Galaxias sp.; $\mathrm{x}=4.8 \mathrm{~cm} \mathrm{SL}, \mathrm{SD}=0.78$, $\mathrm{N}=8$ ). This observation would classify the robalo as an opportunistic predator. Further conclusions can only be reached after more comprehensive energetic studies on prey species and ethological and physiological aspects of E. maclovinus. It should be noted that $G$. maculatus is a pelagic, schooling species, which may occur just below the surface, over the botton, and or even near the shoreline (Pequeño 1981), meanwhile the robalo is a preferently benthonic species.

Based on the information presented above, and given the broad trophic niche occupied by the robalo, this species could be considered as a generalized predator (sensu Jaksic 2000). Also, since as a general tendency (Fig. 3) this species exploits resources when they occur in greater abundance in the environment (e.g., P. hartmannorum, Chironomidae) (sensu Morin 1999, Jaksic 2000).

In spite of the apparent contradiction within the characterization of E. maclovinus' type of predation, it indeed maintains its position as a carnivore both on the basis of its' stomach contents and the quantity of parasites in them, as well as the low degree of digestion of the plant matter present in the stomachs. The number of nematode parasites found during the winter was lower both in $\% \mathrm{~F}$ and $\% \mathrm{~N}$ when compared with data obtained by Pavés et al. (2005) although the percentages of adult stages of Ascarophis sp. (Cysticolidae) and larvae and adults of the anisakids was similar.

The present study suggests that added to a euryzoophagia (Pequeño 1979, Turner 1988, Acevedo 1994), E. maclovinus is able to feed with no trouble on limnetic resources which undergo seasonal variation in the environment over time. This characteristic is coherent with the capacity of the species for penetrating freshwater habitats. It's also in agreement with the results of Pavés et al. (2005), where no seasonal comparisons were made.

Although the trophic spectrum of the robalo in the Valdivia River is considered to be broad, it is not as broad as that of the same species inhabiting marine and mixohaline environments (Pequeño 1979, Isla \& San Román 1995). This situation may be related as much to selectivity by the predator as to the low species diversity in the upper reaches of an estuary (Low 1993, García \& Ojeda 1995) in comparison with the diversities found in marine or lacustrine environments (Kiely 1999). 
In summary, the results here presented showed that although there was seasonal variation in the diet of the robalo of the Valdivia River estuary, predator pressure was probably independent of the abundance of prey species in the environment. This condition suggests that the robalo is a selective predator. If the quantity of it's main prey item becomes reduced, E. maclovinus broadens its trophic spectrum towards other animal species present in greater abundance, marking it as an opportunistic predator. In all cases, the robalo remains a carnivore over time. The carnivorous habit is further indicated by the presence of large numbers of nematode parasites of crustacean prey found in the robalo stomachs.

\section{ACKNOWLEDGMENTS}

To Carlos Jara, Maritza Mercado, Alejandro Bravo, Wladimir Steffen and León Matamala, all of them from the Instituto de Zoología, UACH; Jorge Jaramillo, Carlos Ramírez and Miguel Alvarez (Instituto de Botánica, UACH); M. Teresa González, from the Doctoral Program, UACH (Academic of Universidad de Antofagasta); M. Eliana Ramírez and Mélica Muñoz (Museo Nacional de Historia Natural, Santiago), for their support in species identification and manipulation in the Laboratory. Louis DiSalvo greatly helped with English language. HPH was supported by the UACh and the MECESUP program (AUS 001-11). These are partial results of the Project S-2005-03 of the Universidad Austral de Chile, to the main author.

\section{BIBLIOGRAPHY}

Acevedo, A. 1994. Comparación de la alimentación de Eleginops maclovinus (Valenciennes, 1830) en base a muestreos de 1974 y 1991 para la zona de Mehuín, Chile (Teleostomi, Nototheniidae). Tesis de Licenciado en Biología Marina. Facultad de Ciencias Universidad Austral de Chile. Valdivia. XL $+35 \mathrm{pp}$.

Andres, H. G. 1979. Paracorophium hartmannorum sp.n. aus dem Eulittoral der chilenischen Pazifikkuste (Crustacea, Amphipoda). Mitteilungen aus dem Hamburgischen Zoologisches Museum und Institut 76: 381-385.

Artigas, J., E. Campusano \& U. GonzÁlez. 1985. Contribución al conocimiento de la biología y hábitos alimentarios de Salmo gairdneri (Richardson, 1836) en lago Laja (Chile) Gayana Zoología 49 (1-2): 3-29.

Bertrán, C. 1989. Zonación y dinámica temporal de la macroinfauna intermareal en el estuario del río Lingue (Valdivia, Chile). Revista Chilena de Historial Natural 62:19-32.

Calvo, J., E. Morriconi, G. Rae \& N. San Román. 1992. Evidence of protandry in subantarctic notothenid, Eleginops maclovinus (Cuv. \& Val.,1830) from the Beagle Channel,
Argentina. Journal of Fish Biology 40: 157-164.

Fagerholm, H. \& B. Berland. 1988. Description of Ascarophis arctica Poljansky, 1952 (Nematoda: Cystidicolidae) in Baltic Sea fishes. Systematic Parasitology 11: 151-158.

Fagerholm, H. \& E. Butterworth. 1988. Ascarophis sp. (Nematoda: Spirurida) attaining sexual maturity in Gammarus spp. (Crustacea). Systematic Parasitology $12: 123-139$

García, V. \& C. OJedA. 1995. Estructura del bentos en áreas con enriquecimiento orgánico en el complejo estuarial de los ríos Calle-Calle, Valdivia y Cruces. Tesis para optar al Grado de Licenciado en Biología Marina. Universidad Austral de Chile. XXVIII $+30 \mathrm{pp}$

Gosztonyi, A. 1974. Edad y crecimiento del "Róbalo" Eleginops maclovinus (Osteichthyes, Nototheniidae) en aguas de la ría Deseado y sus adyacencias. Physis 33(86):1-8.

Gosztonyi, A. 1979. Biología del "robalo" (Eleginops maclovinus (Cuv. \& Val., 1830). Tesis Doctoral. Facultad de Ciencias Exactas y Naturales, Universidad Nacional de Buenos Aires. Agosto de 1979. 129 pp.

Gottsberger, G. 1978. Seed dispersal by fish in the inundated regions of Humaita, Amazonia. Biotropica 10(3): 170-183.

GuzmÁn L. \& I. CAmpodónico. 1973. Algunos aspectos de la biología de Eleginops maclovinus. (Cuv. y Val.) 1830, con especial referencia a su morfometría, caracteres merísticos y alimentación. Anales del Instituto de la Patagonia 4 (1-3) 343-371.

Isla, M. \& N. SAN Román. 1995. Alimentación de Eleginops maclovinus (Pisces, Nototheniidae) en el Canal Beagle, Argentina. Naturalia 3(1-2):107-127.

JAKSIC, F. 2000. Ecología de comunidades. Ediciones Universidad Católica de Chile, Santiago, 233 p.

Jaramillo, E., S. Mulsow \& R. Navarro. 1985. Intertidal and subtidal macroinfauna in the Queule River Estuary, South of Chile. Revista Chilena de Historia Natural 58:127-137.

Kiely, G. 1999. Ingeniería Ambiental. Fundamentos, Entornos, Tecnologías y Sistemas de Gestión. McGraw Hill, Madrid, España, 1331 pp.

Klink, A. \& R. EcKmann. 1985. Age and Growth, Feeding Habits, and Reproduction of Cauque mauleanum Steindachner 1896 (Pisces: Atherinidae) in Southern Chile. Studies on Neotropical Fauna and Environment 2(4): 239-249.

Licandeo, R., C. Barrientos \& M.T. GonzÁLEZ. 2006. Age, growth rates, sex change and feeding habits of notothenioid fish Eleginops maclovinus from the central-southern Chilean coast. Environmental Biology of Fish 77:51-61.

Low, A. 1993. Distribución y estructura de la pequeña macroinfauna estival en estuarios micromareales del sur de Chile. Tesis para optar al Grado de Licenciado en Biología Marina, Universidad Austral de Chile. 53 pp.

Marcogliese, D. 2002. Food webs and the transmission of parasites to marine fish. Parasitology 124:S83-S99.

MenZies, J. 1962. The zoogeography, ecology and systematics of the Chilean marine isopods. Reports of the Lund University Chile Expedition 1948-49. Lunds Universitets Arsskrift. N.F. Avd. 2, Band 57 (11): 1-160.

Morin, P.J. 1999. Community Ecology. Blackwell Science Inc Malden, MA, USA. 424 pp.

Pavés, H., G. Pequeño, C. Bertrán \& L. Vargas. 2005. Limnetic feeding in Eleginops maclovinus (Valenciennes, 1830) in 
Gayana 74(1), 2010

the Valdivia river, Chile. Interciencia 30 (3): 120-125.

Pequeño, G. 1979. Antecedentes alimentarios de Eleginops maclovinus (Valenciennes, 1830) (Teleostomi: Nototheniidae) en Mehuín, Chile. Acta Zoológica Lilloana 35: 207-230.

Pequeño, G. 1981. Peces de las riberas estuariales del río Lingue, Chile. Cahiers de Biologie Marine (Roscoff) 22: 141163.

Pequeño, G. 1989. The geographical distribution and taxonomical arrangement of Southamerican nototheniid fishes (Pisces: Osteichthyes). Boletín Sociedad de Biología. de Concepción 60: 183-200.

Peñaloza, C. 1993. Distribución de la epifauna sobre Gracilaria chilensis Bird, McLachlan \& Oliveia (Rhodophyta, Gigartinales) en el estuario del Río Maullín, X Región, Chile. Tesis para optar al Titulo de Profesor de Biología, Química y Ciencias Naturales, Universidad Austral de Chile. V +63 pp.

PinKas, L., M.S. Oliphant \& I.L.K. Iverson. 1971. Food habits of albacore, bluefin tuna and bonito in Californian waters. California Fish and Game 52: 1-105.

Ramírez, C., M. Romero \& M. Riveros. 1976. Lista de cormófitos acuáticos de la región valdiviana. Boletín Museo Nacional de Historia Natural, Chile 22: 3-12.

Retamal, M. 1981. Catálogo Ilustrado de los Crustáceos Decápodos de Chile. Gayana, Zoología 44. 110 p.

Ronald, C. 1986. A preliminary review of the genus Ascarophis van Beneden, 1871 (Nematoda: Cystidicolidae) of the gastrointestinal tract of fishes. Monograph on Fish
Parasites. Department of Zoology. University of Hong Kong, 54 pp.

RuIz, V. 1993. Ictiofauna del Río Andalién (Concepción, Chile). Gayana, Zoología 57(2):109-278.

SchneIDER, F. \& K. MAnN. 1991a. Species specific relationships of invertebrates to vegetation in a seagrass bed. I Correlational Studies. Journal Experimental Marine Biology and Ecology. 145:101-117.

Schneider, F. \& K. MANn. 1991b. Species specific relationships of invertebrates to vegetation in a seagrass bed. II Experiment on the importance of macrophyte shape epiphyte cover and predation Journal Experimental Marine Biology and Ecology. 145:119-139.

Stuardo, J. 1961. Contribución a un Catálogo de los Moluscos Gasterópodos Chilenos de Agua Dulce. Gayana, Zool., 1: 7-32.

TuRnER, A. 1988 Relaciones tróficas de dos especies bentófagas, Cauque mauleanum (Steindachner, 1902) y Eleginops maclovinus (Valenciennes, 1830) (Pisces: Osteichthyes) en el estuario del río Queule (IX Región, Chile). Tesis para optar al grado de Magíster en Ciencias, Mención Zoología. Facultad de Ciencias. Universidad Austral de Chile. 48 pp.

Vila, I, L. Fuentes \& M. Contreras. 1999. Peces límnicos de Chile. Boletín del Museo Nacional de Historia Natural de Chile. 48:61-75.

Yamaguti, S. 1961. Sistema Helminthum. Vol. III The nematods of vertebrates part. I- II Interscience Publ. Inc., New York. 1135 pp.

Recibido: 21.08 .09

Aceptado: 17.03 .10 